\title{
Evaluation Input of Early Childhood Teacher Education Curriculum Faculty of Education Universitas Negeri Padang
}

\author{
Alwen Bentri \\ Faculty of Education \\ Universitas Negeri Padang \\ Padang, Indonesia \\ alwenbentri@fip.unp.ac.id
}

\begin{abstract}
The purpose of this article is to describe the evaluation input of early childhood teacher education study program curriculum. Input evaluation is intended to find alternative strategies for curriculum implementation. The quality and quantity of inputs as raw materials have a major effect on the transformation of early childhood teachers' education. This study use descriptive qualitative method in early childhood teacher education curriculum faculty of education Universitas Negeri Padang 2017. Input evaluation procedures include; 1) inventory and analyze available learning resources, 2) analysis of budget proposal and schedule, 3 ) analysis of solution strategies, and 4) program implementation plans. Data were obtained from relevant elements of curriculum input evaluation, and then analyzed based on the evaluation principle. The results show that educational curriculum inputs of early childhood teacher education refer to national education standards and consistently consider the goals of faculty and universities until 2020 . Continuing study programs of early childhood teacher education curriculum increase the input of available learning resources to achieve a functional curriculum.
\end{abstract}

Keywords-evaluation of input; curriculum; prospective teachers; early childhood

\section{INTRODUCTION}

The curriculum evaluation is an integral part of a curriculum development cycle and implementation [1]. The curriculum evaluation answers the question, "How do we know whether the objectives of the curriculum and learning have been achieved?" [2]. The answer to that question involves consideration of quality and objectives as a criterion for successful learning. Curriculum evaluation has a domain assessing the implementation of educational programs, analyzing, and informing how far the development and implementation of the curriculum meets the criteria or predetermined standards. Observing implicitly and explicitly, [3] mentions that evaluations reflect assessments of the curriculum and instructional designs that have been implemented; evaluation criticizes the curriculum, learning and its implementation.
Evaluation is a continuous process by which data are gathered and judgments made for the purpose of improving a system [4]. In evaluation process, alternatives are used in terms of evaluation and assessment, and these are often used and used interchangeably [1], but there is agreement that assessment tends to be related to data collection of learning outcomes, interpretations and descriptions of student learning outcomes. While evaluations involve consideration of the value or benefits of student learning outcomes obtained through assessment as a basis for management decisionmaking, curriculum, and students [5]. According to most of the literature, evaluations are related to the activities of measuring student learning outcomes, assessing the competence and progress or achievement of students for the determination of values or numbers. They may be based on predetermined norms or criteria, even if they are based on educators' considerations [6]. Whereas educators' considerations play a major role in determining the number or grade of student learning outcomes, this type of evaluation is considered subjective and less reliable [5]. Upon these considerations, prior to curriculum implementation, the context and input of the curriculum need to be evaluated.

Evaluation is important for each program because evaluation is an early warning system for the program, as well as a study program that produces a teacher education in the Faculty of Education. The urgency of the attendance of the teacher education-producing program is supported by the reason that teachers have an important role in implementing the curriculum. This is because educators interact with learners either in class face to face or outside the classroom in a non-face-to-face form. Faculty of Education that produces educators are Early Childhood Education Studies Program, Elementary School Teacher Education Study Program, and Study Program of Special Education. This article specifies the curriculum evaluation results related to the teacher education curriculum in the Teachers Education Program of Early Childhood Education Faculty of Education Universitas Negeri Padang. On this occasion this article relates and presents the results of input evaluation. Researchers conduct a gradual and continuous research to improve the quality of graduates. After 
performing a context evaluation, the next step is input evaluation.

Input is related to available learning resources and is the initial capital in implementing the curriculum that has been designed. Learning resources, in quality and quantity into inputs that have a major impact on the transformation of curriculum implementation. Since this input has a significant effect on the success of curriculum development in each study program, evaluation of these inputs needs to be done to observe the quality of the inputs. Evaluation includes measurement and assessment processes to collect adequate data useful for deciding on subsequent actions [7]. This study is an evaluation study, often called the input evaluation. Input evaluation is part of the CIPP model evaluation, covering; context evaluation, input evaluation, process evaluation and product evaluation [1], [8] and an appropriate performance evaluation model for higher education institutions [7]. Input evaluation is also called a two-level evaluation and according to [3] is ad hoc and micro analyst.

The input evaluation aims at obtaining information and presenting the information underlying the determination of ways to utilize these resources to achieve objectives [1] and to help identify program needs. The results of input evaluation in the form of procedural design and implementation strategy of the curriculum to achieve the objectives. The focus is to identify and assess the ability of the resources currently available to find and critically examine relevant strategies. In the input evaluation phase, the evaluation is focused on the selection of materials, the analysis of learners, educators, learning resources and the means used to achieve the objectives [1]. Then provide alternative recommendation options for implementing the curriculum. The results of these input evaluations are designed to meet identified needs. The successful implementation of curriculum certainly requires a good plan, and it is stipulated in the planning of learning. Applying the correct design will provide the best service for students. Input evaluation is conducted by meeting the criteria that include, 1) proposed plan, 2) eligibility, 3) strategic advantage, 4) cost, 5) and other cost effectiveness projections. 5 Furthermore a literature search is conducted to help determine the right strategy to implement curriculum. Several alternative implementation strategies, school resources and various program designs are reviewed to find the most effective and economical way $\lceil 9\rceil$ an appropriate performance evaluation model for higher education institutions [10]. So the input evaluation is some kind of procedural feasibility [3].

Viewed from the other side of the evaluation is designed to provide information to determine how to determine and use resources to achieve the objectives that have been formulated. During the evaluation of inputs running, the most effective and efficient alternatives are selected. At the time of choice has been established, all information relevant to the success of the program is collected; evaluated, and ended in curriculum implementation.

\section{METHOD}

This research is an evaluation research, especially related to curriculum evaluation using CIPP model, including evaluation of context, input, process and product. This article describes the part of curriculum evaluation that is the evaluation of curriculum input on the program of Early Childhood Education, Faculty of Education, Universitas Negeri Padang. The Early Childhood Teacher Education Study Program is a study program that produces educator for early childhood or future teachers for Kindergarten. Taking the study as a place and subject of research because the graduates will later educate children who are in golden age. The success and failure of education at this age will be greatly determined by the educators. Therefore for the achievement of children of early age with quality qualified education required smart and professional teachers. Input evaluation procedures include 1) inventorying and analyzing available learning resources, 2) budget and schedule proposals, 3) solution strategies, and 4) program implementation plans. Once the available learning resources are available, a literature search is conducted to determine the curriculum implementation strategy. The collected research data is processed qualitatively and quantitatively.

\section{RESULT AND DISCUSSION}

The input evaluation considers the resources available in the programming agencies, the strategies used in implementing the program, and the plan for how the strategy can be properly implemented [3], [11]. The result of input evaluation of curriculum of educator in Education program of Early Childhood Teachers Education Faculty of Education Universitas Negeri Padang is presented in four sections; First inventory and analyze the available learning resources. Data from 2016-2017, the Early Childhood Education Teacher Education program has 625 students and 23 lecturers who have relevant scholarship with the study program. There are 3 lecturers are studying, 1 permission to learn, and the rest actively teach in the study program. Judging from the ratio of active lecturers with registered students, this study program needs to add lecturers to make healthy and ideal ratios. Active lecturers have complete learning tools including syllabus, teaching materials, broadcast media, and assessment instruments. In addition, other learning resources that support and are important for now is the learning facilities provided by the university to optimize the lecture process, including webmail, platform e-learning, blended-learning, academic portals, e-library, and internet service 24 hours a day. This facility can be utilized by the students because the students have a good initial knowledge shown by the test admission score of the study program has an average of 7.097 on the SNMPTN line, 626 on the SBMPTN line, and 7.36 on the independent selection path.

The second section analyzes the budget and schedule proposals. The budget system is centrally managed by universities. The university allocates budget for each faculty which then the faculty decreases or allocates for each study program in the faculty environment proportionately. Funds that have been allocated to each study program can be obtained through proposed programs and activities required or 
required. Leaders of Teachers Education of Early Childhood has allocated funds and use them to increase the quality of learning in terms of quality or quantity in accordance with the schedule or timing of its use. Education budget is a very important component for the sustainability of curriculum implementation and achieving the objectives that have been determined.

The third section, analyzing curriculum implementation strategies based on the inventory of learning resources and the proposed budget. In this case a literature study was conducted to find out the various forms of implementation strategies and decide the most appropriate strategy used for the situation of the Early Childhood Education Study program of Educational Studies of the State University of Padang. Based on the existing conditions of the education program Teachers of Early Childhood Education have lecturers with relevant scholarship and preliminary student knowledge, learning strategies needed to facilitate and facilitate the implementation of the curriculum is an inquiry strategy. Learning strategies relevant to the objectives and course materials basically lead to how to facilitate learning activities in accordance with the subject matter of each meeting. In other words, the strategy facilitates early childhood educator candidates to conduct various learning activities relevant to the competence of educators so that they gain a comprehensive learning experience, namely; includes knowledge, attitudes and skills. The objective of learning activities is to maximize the learning activities by reducing the teacher's lecture so that what happens is not teaching but learning [12]. This is what needs to be observed when determining curriculum implementation strategies.

Fourth, implementation of the program design. Based on data obtained from the field and literature studies, evaluators recommend that to design the first known program activities that are known and formulated are the objectives of the curriculum itself. Next create a learning design that enables and empowers potential early childhood teacher education. That is, every student is given the opportunity for them to deepen their own lecture materials, the longer the higher the intensity of learning so that these student are able to develop the material into knowledge and experience. In other words, only with the activeness of this students they learn and deepen the competence of early childhood teacher education. As it says [2] that what the student is learning is what he does not what his lecturer does. This statement is closely related to the role of educators and the role of early childhood educator candidates, where the role of educator candidates to learn, explore and process existing knowledge becomes a functional experience later on when become an educator.

\section{CONCLUSION}

Designing curriculum implementation planning needs to be done carefully and by considering many things, such as; goals, learning experiences, strategies, and learning resource needs. Furthermore, to support and smoothen the implementation of curriculum undertaken, at this stage of the input leads to giving consideration in paying attention to learning strategies and learning resources or learning facilities needed and used to achieve goals. The data has been summarized indicating that, learning strategies and learning resources are basically in quality and quantity is sufficient and relevant to implement the curriculum of students in Early Childhood Teacher Education Study Program.

\section{Acknowledgment}

The authors would like to thank all those who contributed to completion of this article. Thanks also to the research fund provider, Universitas Negeri Padang.

\section{References}

[1] M. Ansyar, 'Kurikulum; Hakikat, Fondasi, Desain dan Pengembangan', pp. 486-489, 2015.

[2] R. W. Tyler, 'Achievement testing and curriculum construction', Trends student Pers. Work, vol. 3914107, 1949.

[3] A. C. Ornstein and F. P. Hunkins, 'Curriculum: Foundations, Principles and Issues Prentice Hall', New Jersey Englewood Cliffs, 1988.

[4] P. F. Oliva, 'Developingthe Curriculum'. Little, Brown \& Company Limited, 1982.

[5] L. Brady and K. Kennedy, Curriculum construction. Pearson Higher Education AU, 2013.

[6] W. H. Schubert, Curriculum: Perspective, paradigm, and possibility. Pearson College Division, 1986.

[7] M. Print, Curriculum development and design. Allen \& Unwin, 1993.

[8] D. L. Stufflebeam and A. J. Shinkfield, 'Evaluation Theory, Models, and Applications'. Jossey-Bass, San Francisco, CA Google Scholar, 2007.

[9] J. P. Miller and W. Seller, Curriculum Perspectives and Practice. ERIC, 1985.

[10] R. Chinta, M. Kebritchi, and J. Elias, 'A conceptual framework for evaluating higher education institutions', Int. J. Educ. Manag., vol. 30, no. 6, pp. 989-1002, 2016.

[11] H. S. Tokmak, H. M. Baturay, and P. Fadde, 'Applying the context, input, process, product evaluation model for evaluation, research, and redesign of an online master's program', Int. Rev. Res. Open Distrib. Learn., vol. 14, no. 3, pp. 273-293, 2013.

[12] M. Ansyar, 'Kurikulum dalam Menyongsong Otonomi Pendidikan di Era Globalisasi (Peluang, Tantangan danArah)', in Seminar Pelaksanaan Otonomi Pendidikan dalam Era Globalisasi, 2000. 